\title{
Individual identification of Crocodylus intermedius (Orinoco crocodile) using tail spot patterns
}

\author{
Alvaro Velasco Barbieri ${ }^{1}$ \\ 1. Fauna Silvestre productos y servicios, Av La Trinidad edif Iguapo apto 52 Santa Paula El Cafetal Caracas, Venezuela; \\ velascocaiman@gmail.com,
}

ABSTRACT. Introduction: The Conservation Action Plan of the Orinoco crocodile (Crocodylus intermedius) includes the release of captive-bred specimens back into the wild. By monitoring these specimens in their natural habitat their adaptability is examined. However, an accurate identification system is necessary to recognize the individuals when they are recaptured. Objective: Determine if Swanepoel or Boucher, Tellez and Anderson crocodile identification methods are useful for the Orinoco crocodile. Methods: A total of 543 Orinoco crocodiles were photographed and each photo was vectorized by drawing dark spots greater than $25 \%$ for each scute, in the first 10 lines of double caudal scales of the tail on the right side. Two system codes were evaluated, one is a numeric code described by Swanepoel and the other is an additive code described by Boucher, Tellez and Anderson. Results: A total of 464 Swanepoel codes and 537 Boucher, Tellez and Anderson codes based on the dark spot pattern of the scales on the right side of the tails were generated for the 543 specimens. Both methods yielded high code values, however, the one developed by Boucher, Tellez and Anderson, with a 98.90\% differentiation of the analyzed specimens, worked better. Conclusion: The study confirms that using the method of spots in the tail of crocodiles is an effective tool for identifying individual crocodiles.

Keywords: Conservation, management, individual identification, Crocodylus intermedius, mark-recapture.
RESUMEN. "Identificación individual del Crocodylus intermedius (Caimán del Orinoco) utilizando el patrón de manchas en la cola". Introducción: El Plan de acción para la conservación del caimán del Orinoco (Crocodylus intermedius) entre sus actividades está la liberación de las poblaciones naturales con ejemplares criados en cautiverio, por medio del seguimiento de dichos ejemplares en su hábitat natural se evalúa su adaptabilidad, pero es necesario un sistema de identificación que permita reconocer los ejemplares cuando son recapturados. Objetivo: Determinar si el método de identificación de cocodrilos propuestos por Swanepoel o Boucher, Tellez y Anderson es aplicable en el caimán del Orinoco. Metodología: Se fotografiaron 543 caimanes de Orinoco y cada foto se vectorizó dibujando puntos oscuros mayores al $25 \%$ en cada escama, en las primeras 10 líneas de escamas dobles caudales de la cola en el lado derecho, se usaron dos sistemas de codificación, uno es un código numérico descrito por Swanepoel y el otro es un código aditivo descrito por Boucher, Tellez y Anderson. Resultados: Se generaron 464 códigos Swanepoel y 537 códigos Boucher, Tellez y Anderson basado en el patrón de coloración oscura de las escamas del lado derecho de las colas. Ambos métodos arrojaron altos valores de códigos, sin embargo, funciono mejor el desarrollado por Boucher, Tellez y Anderson, con un $98,90 \%$ de diferenciación de los ejemplares analizados. Conclusión: El estudio ratifica que utilizar el método de las manchas en la cola de los cocodrilos es una herramienta eficaz en la identificación de los individuos.

Palabras clave: Conservación, manejo, identificación individuos, Crocodylus intermedius, marcaje-recaptura. 
The Action Plan for Conservation of the Orinoco crocodile (Crocodylus intermedius) in Venezuela (Velasco, 2003) was published by the National Biological Biodiversity Office of the Ministry of Environment and Natural Resources in 2003 and complemented by the Venezuela Crocodile Specialist group in its publication where they describe the strategy for the conservation the Orinoco crocodile (GECV, 2007). Both documents include the reintroduction of juveniles raised in captivity and monitoring their adaption to life in the wild, in order to recover the wild populations.

To evaluate the extent to which the released crocodiles adapt, it is necessary to implement capture and recapture techniques. Therefore, each specimen has to have a unique identification mark in order to record its baseline morphometric data when it is released, and then to compare when it is recaptured.

Brazaitis (1973) in his identification key used the pattern of the nuchal and dorsal scales to separate different crocodile species. However, for this study the question was how to recognize individuals of the same species. The method most used is based on the pattern of the nuchal and post occipital scales. Garrick (1982) used this technique in Jamaica to analyze the patterns of nuchal and post occipital scales in Crocodylus acutus. Seijas (2002) in Venezuela also found that the American crocodile showed a high variability of nuchal and post occipital scale patterns. GarciaGrajales, Buenrostro and Tellez-Rodriguez (2009) working in Mexico recognized 33 different patterns in 111 American crocodiles. Similar observations were made by Platt, Thorbjarnarson and Rainwater (2012) working with Crocodylus acutus in northern Belize. Another method was developed by Balaguera-Reina, Venegas-Anaya, Rivera and Desmore (2017) and Forero, Lozano and Balaguera-Reina (2019) where they describe the patterns based on the numbers and positions of dorsal scales in Crocodylus acutus in Coiba Island Panama.

However, all these methods are somewhat complicated to apply for the identification of individual specimens of a particular species. Swanepoel (1996) developed a simple method to identify each crocodile based on the natural spotting on both sides of the tail for Crocodylus niloticus, generating a unique code for each individual and found that it differentiated $95.1 \%$ of the crocodiles. Boucher, Tellez and Anderson (2017) used the Swanepoel method and added a modification that included the dark spots of the double caudal scales in Crocodylus acutus and Crocodylus moreletii in Belize, and reported that $99 \%$ of the codes were different.

After evaluating these techniques, we decided to use the Swanepoel and Boucher et al. methods to investigate in the Orinoco crocodile (Crocodylus intermedius) to determine if there are differences in the pattern on the right side of the tail of individuals. The main reason to use these methods are that tail spot identification provides an accurate and passive method that involves little training of personnel and does not require expensive specialized equipment (Boucher et al., 2017).

\section{MATERIALS AND METHODS}

The sample consisted of 543 Orinoco crocodiles (Crocodylus intermedius) from Capanaparo River Apure State $(n=1)$; El Frio ranch Apure State in captivity $(n=1)$; Parque del Este Zoo in Caracas $(n=1)$; El Cedral ranch, Apure State ( $n=57$, captive reared prior to release into natural habitat); and Masaguaral Ranch in Guarico State ( $n=484$, captive reared prior to release into natural habitat). Morphometric measurements (total length and weight) were taken and the right side of the tail was photographed for each crocodile.

Each photograph was vectorized by drawing dark spots greater than $25 \%$ of each scale in the first 10 lines of double caudal scales of the tail on the right side (Figure 1). To determine the pattern of the right side of the tail it's used two different methods. One is the numeric code described by Swanepoel (1996) for Crocodylus niloticus and the other is an additive code described by (Boucher et al., 2017) for Crocodylus acutus and Crocodylus moreletii. 


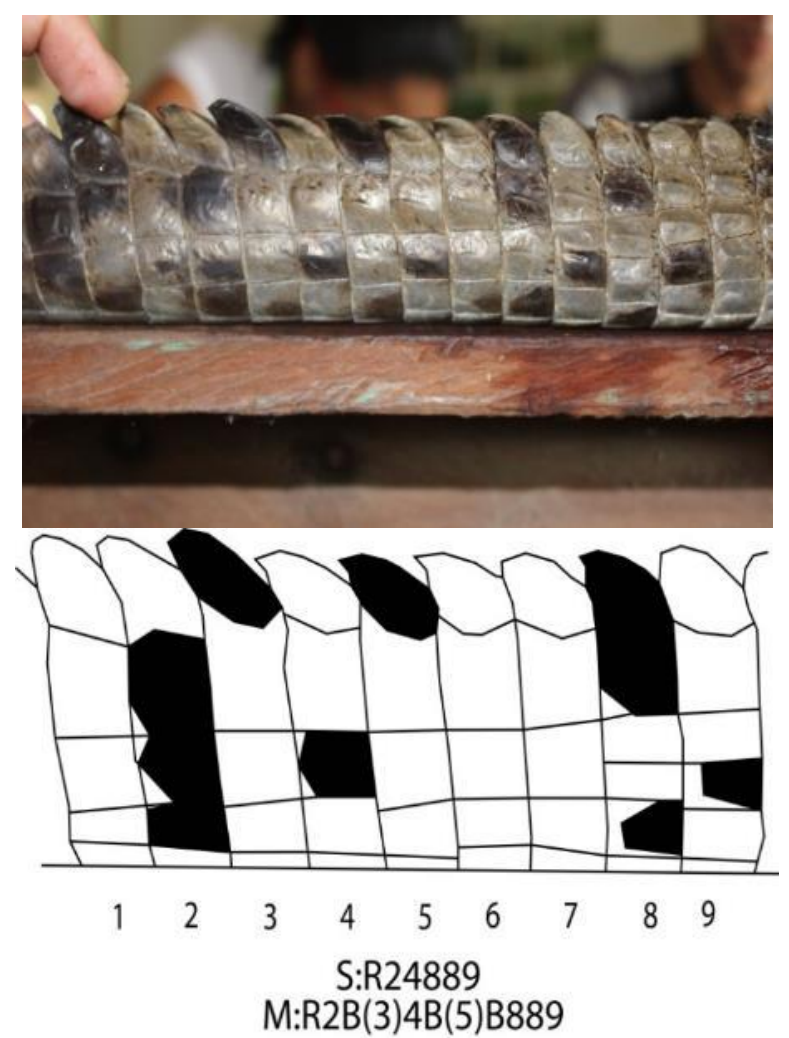

Fig. 1. A) Photograph of sample 095 B) Vector of tail scale pattern sample 095

The difference between both techniques is described by Boucher et al. (2017). Swanepoel's method assigns a numeric value for the presence of dark markings on the caudal scales. Boucher et al. (2017) adapted Swanepoel's method by adding the dark vertical scutes (double caudal scales) and irregular scale groups.

In our study, it's made some modifications to the methodologies used by Swanepoel and Boucher et al. The main methodological difference is that we analyzed the patterns of the spots only on the right side of the tails, from the last double scale row posteriorly to single row \#10. This methodological change was due to the variability observed in the tail patterns and the fact that when sunning in the wild it is easier to photograph that portion of the tail in this species. Table 1 compares the methodologies used by us, Swanepoel and Boucher et al.

It was created a dataset that included for each Orinoco crocodile the number of samples and vector images, the total length and weight, the metallic mark identification, and the Swanepoel and Boucher et al. code. For each method we searched for repeated codes. All repeated codes were reviewed with the vector images to confirm that they were the same code. 
TABLE 1

Comparison of methods for determination the tail-spot pattern codes.

\begin{tabular}{|c|c|c|}
\hline Swanepoel (1996) & $\begin{array}{c}\text { Boucher, Tellez and Anderson } \\
\text { (2017) }\end{array}$ & This study \\
\hline Left and right sides & Left and right sides & Right only \\
\hline $\begin{array}{l}\text { Vertical tail scales from double rows } \\
1-9\end{array}$ & $\begin{array}{l}\text { Vertical tail scales from double } \\
\text { rows } 1-9\end{array}$ & $\begin{array}{l}\text { Vertical tail scales from double rows } \\
1-10\end{array}$ \\
\hline Double scale row not included & Double scale row included & Double scale row included \\
\hline $\begin{array}{l}\text { When the mark extends across two } \\
\text { rows it is reported as [34] }\end{array}$ & $\begin{array}{l}\text { When the mark extend across two } \\
\text { rows it is reported as " } \mathrm{B} \text { " before the } \\
\text { row number }\end{array}$ & $\begin{array}{l}\text { Does not use any special recording } \\
\text { for extended marks across adjacent } \\
\text { rows }\end{array}$ \\
\hline $\begin{array}{l}\text { Does not report double scale } \\
\text { markings }\end{array}$ & $\begin{array}{l}\text { Reports the double scale mark by } \\
\text { "I" before the row number }\end{array}$ & $\begin{array}{l}\text { Reports the single scale in } \\
\text { parenthesis }\end{array}$ \\
\hline
\end{tabular}

\section{RESULTS}

Were analyzed the 543 photographs of Orinoco crocodiles from the Capanaparo River, El Frio Ranch, El Cedral Ranch, Masaguaral Ranch and Parque del Este Zoo. Total length of individuals measured between $315 \mathrm{~mm}$ to $2270 \mathrm{~mm}$, with an average of $648,37 \mathrm{~mm}$. Were recorded weight of individuals between $125 \mathrm{~g}$ to $4900 \mathrm{~g}$, with an average of $1007,76 \mathrm{~g}$. The results are summarized in Table 2. The Swanepoel code generated 464 tail patterns with 79 repetitions representing $17,03 \%$ of the sample. The Boucher et al. code generated 537 tail patterns with 6 repetitions (1,12\%).

TABLE 2

Summary of results with Swanepoel and Boucher, Tellez and Anderson codes

\begin{tabular}{lcc}
\hline & $\begin{array}{c}\text { Swanepoel } \\
\text { Code }\end{array}$ & $\begin{array}{c}\text { Boucher, Tellez } \\
\text { and Anderson } \\
\text { Code }\end{array}$ \\
\hline Sample size & 543 & 543 \\
LT (mm) & 648,37 & 648,7 \\
W $(\mathrm{gr})$ & 1007,76 & 1007,76 \\
Localities samples & 5 & 5 \\
Codes Number of codes number generated & 464 & 537 \\
Percentage of different codes & $85,45 \%$ & $98,90 \%$ \\
Number of repeated codes & 79 & 6 \\
Percentage of repeated codes & $17,03 \%$ & $1,12 \%$ \\
\hline
\end{tabular}

Swanepoel method generated 79 repeated codes. Figure 2 shows the frequency of Orinoco crocodiles per codes, where 56 codes with a two $C$. intermedius, 13 codes with 3 crocodile, 7 codes with 4 animals, and 3 different codes with 5, 6 and 10 individuals.

Boucher, Tellez and Anderson method generated 6 repeated codes, all with two crocodiles. The statistical analysis through Chi square test demonstrate significant differences between both methods $\left(X_{1,543}^{2}=33,58 ; P<0,001\right)$, where Boucher, Tellez and Anderson method generated more codes for crocodiles analyzed that permit differentiate the sample. 


\section{Frequency of crocs number per Swanepoel Code}

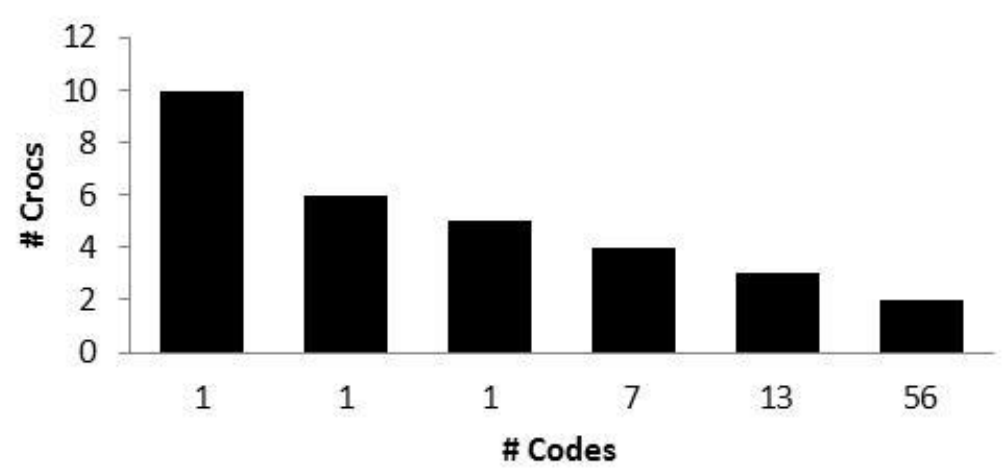

Fig. 2. Frequency of Orinoco caiman per Swanepoel code.

\section{DISCUSSION}

In Venezuela with the Crocodylus intermedius Conservation Program, one of the tools implemented is a captive breeding and ranching program to increase the natural populations.

When a crocodile is born, two identification systems are used. One is placing interdigital numbered metal plates on the hind legs and the other is, cutting off single tails scales. This system allows each specimen to be identified during their time in captivity. At the time of releasing them into the wild their development is known and another slightly larger metal plate is placed for future evaluation when recaptured.

One of the problems with the use of metal plates is that they tend to get lost or oxidized by the action of water (Eversole, Henke, Ballard, \& Powell, 2014; Bouwman \& Cronje, 2016; Coetzee, Ferreira, \& Maciejewski, 2018), and with the cutting of single scales, some specimens suffer the loss of part of the tail due to infection or the cut scales regenerate. This has meant in some occasions, it is possible that when we recapture the specimen there may be no way to identify it and know if it was reintroduced or born in its natural habitat. The modified technique described here has the potential to supplement the identification of recaptured specimens.

The results so far have been promising. Photographs of the tails and morphological data have been taken in the different farms, and the specimens released into their natural habitat. Some Orinoco crocodiles have been recaptured in the Capanaparo River, Apure state, and five of them corresponded to specimens analyzed in the present work. None had lost their metal plate or part of the tail. However, were took new photographs to assess whether changes in the patterns had occurred. It was found that there was no variation in the tail spot patterns previously assigned to each Orinoco crocodile. In conclusion, this study shows that the method used for assigning the tail spot pattern works for identification purposes in the ongoing Orinoco crocodile conservation program and confirm the Boucher et al. (2017) reports. 


\section{ACKNOWLEDGEMENTS}

We would like to thank the many people who helped us with handling the individual crocodiles in order to take the photographs including: Samuel Hilevski, Omar Hernandez, Rosangela Nuñez, Leonel Ovalles, Janel Alas, and Saul Ortega. The Masaguaral ranch, El Cedral ranch, El Frio ranch, and Parque del Este Zoo gave us permission to work in their installations. Daniela Sanchez helped with the translation of the document. Steve Gorzula for reviewed the English edition.

\section{ETHICAL, CONFLICT OF INTEREST AND FINANCIAL STATEMENTS}

The authors declare that they have fully complied with all pertinent ethical and legal requirements, both during the study and in the production of the manuscript; that there are no conflicts of interest of any kind; that all financial sources are fully and clearly stated in the acknowledgments section; and that they fully agree with the final edited version of the article. A signed document has been filed in the journal archives.

The percentage of total contribution for the conceptualization, preparation and correction of this article was A.V.B. $100 \%$.

\section{REFERENCIAS}

Balaguera-Reina, S., Venegas-Anaya, M., Rivera, B., \& Desmore, L. (2017). Scute patterns as an individual identification tool in an American crocodile (Crocodylus acutus) population on Coiba Island, Panama. Journal of Herpetology, 51(4), 523-531.

Boucher, M., Tellez, M, \& Anderson, J. T. (2017). A tail of two crocs: coding tail-spot patterns of individual identification of American (Crocodylus acutus) and Morelet's (Crocodylus moreletii) crocodiles. Mesoamerican Herpetology, 4(4), 760-772.

Bouwman, H., \& Cronje, E. (2016). An 11-digit identification system for individual Nile crocodiles using natural markings. Koedoe, 58(1), a1351. DOI: 10.4102/koedoe.v58i1.1351

Brazaitis, P. (1973). Identification of living crocodilians. Zoológica, 58(1-4), 58-102.

Coetzee, B. W. T., Ferreira, S. M., \& Maciejewski, K. (2018). Challenges and opportunities for monitoring wild Nile crocodiles with scute mark-recapture photography. Koedoe, 60(1), a1505. DOI: 10.4102/koedoe.v60i1.1505

Eversole, C. B., Henke, S. E., Ballard, B. M., \& Powell R. L. (2014). Duration of marking tags on American Alligators (Alligator mississippiensis). Herpetological Review, 2014, 45(2), 223-226.

Forero, M., Lozano, J., \& Balaguera-Reina, S. (2019). Individual identification automation in Crocodilians throught imagery processing: American crocodile as a study case. Proc. SPIE 11137, Applications of Digital Image Processing XLII, 111372A.

Garcia-Grajales, J., Buenrostro, A., \& Tellez-Rodriguez, P.R. (2009). Variación de patrón de escutelación nucal del cocodrilo americano (Crocodylus acutus Cuvier 1807) en La Ventanilla, Oaxaca, México. Acta Zoológica Mexicana, 25(2), 375382.

Garrick, L. D. (1982). Variation in postoccipital and nuchal scale patterns of American crocodiles (Crocodylus acutus). American Zoologist, 22(4), 906.

GECV. (2007). Estrategia nacional para la conservación del caimán del Orinoco en Venezuela y su Plan de Acción. In: Seijas, A. E. (Ed.). Memorias del III Taller para la conservación del caimán del Orinoco, San Carlos, Venezuela. Biollania edición especial N8: 77-86. 
Platt, S., Thorbjarnarson, J., \& Rainwater, T. (2012). Scalation of the American crocodile, Crocodylus acutus (Crocodylidae, Crocodylia), from the coastal zone of northern Belize. Caribbean Journal of Science. 46(2-3),332-338.

Seijas, A. E. (2002). Scale patterns of American crocodile (Crocodylus acutus) from several Venezuelan localities. Revista Unellez de Ciencia y Tecnología,20, 188-134.

Swanepoel, D. G. J. (1996). Identification of the Nile crocodile Crocodylus niloticus by the use of natural tail marks. Koedoe, 39(1), 113-115.

Velasco, A. (2003). Plan de acción para la conservación del caimán del Orinoco (Crocodylus intermedius). Oficina Nacional de la Diversidad Biológica, Ministerio del Ambiente y de los Recursos Naturales. 14 pp. 